\title{
The Relation of Gender and Feminism in Islamic Jurisprudence
}

\author{
Fokky Fuad Wasitaatmadja \\ Al Azhar Indonesia University, Faculty of Law, South Jakarta, INDONESIA \\ Susianto \\ Merdeka Malang University, Faculty of Law, East Java, INDONESIA \\ Suartini \\ Al Azhar Indonesia University, Faculty of Law, South Jakarta, INDONESIA
}

Received: 21 August 2020 - Accepted: 1 October $2020 \cdot$ Published Online: 10 October 2020

\section{Abstract}

\begin{abstract}
Research on the relation of gender in Islamic Jurisprudence field always sparks the interest to study because of several things: the idea of power relations which has been touted as a thought that subordinates the role of women in their dynamic movements. Second, the role of the text of the Holy Qur'an in seeing and explaining gender relations in Islam, specifically when influencing or influenced by local culture. The main research question to be revealed is: how does the concept developed in Islamic Jurisprudence schools interpret the relations of men and women? The theoretical framework developed in this study is based on the thought which built in the Islamic Jurisprudence Schools. Sachiko Murata sees that there is a relationship between cultural understanding and the understanding of God in the relationship of men and women. The research method applied in this research is prescriptive normative legal method with conceptual approach. The conclusion in this study states that in the narrative approach to the Holy Qur'an, there is no significant power relation that degrades, dominates, or subordinates the role of women in Islam. Spatial structure of culture becomes a matter of concern when there is submission in the role of women in their socio-cultural environment. The narrative text of the Holy Qur'an explains the high appreciation of domestic and public roles for women. Feminism itself can be traced in various narrative texts in the Holy Qur'an that place women in a place of honor.
\end{abstract}

Keywords: feminism, gender, Islamic Jurisprudence.

\section{Introduction}

The idea of feminism in epistemological discourse is an interesting topic to explore. Research on the role of women in the sphere of socio-culture and religion becomes interesting to discuss due to several things: First, that in human civilization, there are power relation in relations to the role of women. Indeed, the religious messages in the texts of the Holy Book provide a space of togetherness, as well as equality for anyone regardless of one's gender. On the other hand, appears power relation that is a relationship between certain social groups, where one group dominates another group. The group that dominates can force its will, even oppressing and not giving room for freedom of expression in any existing social arena.

(C) Authors. Terms and conditions of Creative Commons Attribution 4.0 International (CC BY 4.0) apply. Correspondence: Fokky Fuad Wasitaatmadja, Al Azhar Indonesia University, Faculty of Law, Jl. Sisingamangaraja, Kebayoran Baru, South Jakarta 12110, INDONESIA. E-mail: fokkyf@uai.ac.id. 
Second, that the relationship between men and women is a relationship between humans with all the values of civilization in it. The narrative text of the Holy Book will be thought according to what humans think about themselves and their environment, as well as their history. The narrative of the Holy Book, which seen as God's narration, is translated into civilized human behavior. In the structure of culture, there will be various meanings to the narratives of God's Holy Book in accordance with the cultural environment that shapes the natural world of thinking. In relation to feminism, obviously it will be seen as rules in the relationship between men and women in the religious and cultural domains.

Based on those two issues, then the research question going to be explored here is how does the concept of Islamic Jurisprudence see the relation between men and women? The objective of this study is to find how the construction of relation between men and women in the approach of Islamic Jurisprudence School.

\section{Methods}

The research method applied in in this study is doctrinal normative legal research, or the normative prescriptive. A research that use doctrinal normative like this was conducted by analyzing several legal sources, both in the narrative of the Holy Qur'an as the supreme source of law in Islamic Jurisprudence, various notes and sources of feminism thought in Islamic Jurisprudence as the main research source. Research by conducting a study on the understanding of Feminism in Islamic Jurisprudence using conceptual approach. The purpose of this method is to see how the concept of philosophical thought that is built in the Islamic Jurisprudence School of the originality of feminine thought contained in the school.

Theoretical framework that employed in this research was using the analysis of Feminist Legal Theory. It is a theory developed by Sachiko Murata by analyzing the narrative text of the Holy Qur'an that contains various supermen ideas in the context of relationship between men and women. Not only in the relation between humans, but also in theological relation that covers the form of feminism. There is a match to the understanding on the concept of yin-yang which understood in the culture of Chinese society on the relation of gender in Islam. In a more practical level, we can think further, the relation of gender in Islamic Jurisprudence which influenced by existing idea about gender in the idea of culture, and vice versa as taken from the core of Islam itself.

\section{Results and discussion}

Feminism implies an awareness to the existence of oppression or subordination of women due to gender differences, and this is followed by an effort to eliminate oppression and subordination as well as an effort to support gender equality between men and women. The relationship between men and women should more emphasize on their role in life. Not based on physical perception, but looking at the social roles of men and women (Nurmila, 2011: 34).

The patriarchal perception binds so strongly in relations between men and women. The role of men as leaders for women gives the meaning of a process of submission to oppression in certain areas. Power relations place a person in a certain position in a social relationship, as well as in the interactions created in that relationship (Susanto, 2019: 85). The relations between leader and subordinate show a strong hierarchical relationship. Leaders can control, regulate, and dominate the interactions with his/her subordinates. Subordinates will follow the leader's will because of the dominance of power over him. Apparently, what created in such interaction is not an equal relation, but rather hierarchical and dominant. In the world of patriarchy, there is a predominance of men that controls women groups. 
In different interpretation, power relations can also be interpreted positively. Foucolt sees that power relations become a system of control over behavior in an effort to create an order. Control over behavior can be carried out towards everyone by anyone. Power relations should not be interpreted as an effort to control through dictatorship, but rather be carried out through various implemented regulations and norms (Priyanto, 2017: 181). Control over humans, even though through norms will display submission even if it is disguised. It does not subjugate through the process of dictatorship but through various norms of laws which constructed according to the wishes of the patriarch.

The Holy Book tries to explain feminine-masculine relations in a balance view. Both share a balanced role in their socio-cultural role. Allah states that anyone who does good deeds both men and women in a state of faith, then Allah will bestow the reward better than what they have done (Qs. An-Nahl [16]: 97). In another verse, Allah affirms that Allah does not dissipate the good deeds done by both men and women, some of you are descendants of others (Qs. Ali Imraan [3]: 195). From the two narratives from the text of the Holy Book, it is evident that good deeds done by both men and women will be judged the same before Allah. Therein lies Allah's justice, He accepts good deeds done by both men and women. God looks at the good deeds done by human without discriminating the gender. The position of women is the same as men in carrying out their social activities.

There is a religious space for humans in the idea of feminism. It is not secularly separated from theological spiritualism. In essence, feminism is ontologically always placed on the idea of obedience to God. Therefore, the use of headscarves and all clothing that covers women's body, which often objected by sharp criticism, is not a form of anti-feminism. In this situation we can see the role of women in a position to contribute in the making of changes in the mindset of society. Headscarves and clothing are not interpreted as a form of exploitation of women, but rather are understood as a form of choice for women to follow the spirit of spiritualism. Women will be seen in the process of socio-cultural movements and not in what they wear. Women in dynamic sociocultural environments and arenas demand an active role. The freedom to decide whether to wear or not to wear hijab is more a choice of free will, and should not be interpreted as a form of oppression to women's position.

In the context of European thinking, the subordinating process on women's role in social arena makes women lost their competence rights. Patriarchy put a role of tyranny and total control on women rights. It fully recognizes that the relation is constructed on masculine paradigm whose character is conquering. Some legal norms were created based on men's volition, such as man's position as leader in various social, cultural, and religious levels. The law is constructed according to the patriarchal will, because the world is created as he wishes.

The process of cultural reinterpretation towards the meanings of God's scriptures will turn differently from the implementation. Issues and problems relating the role of women will be deeply affected by the local conditions. The problem of polygamy in Indonesia, the issue of political role of women in Afghanistan, and many other locality problems raise quite attention in gender study. In Indonesia, the issue of polygamy is a form of Indonesian men's efforts to show off their hegemony and masculinity in his social environment (Ghosh, 2009: 3). On the other side, the efforts to support women rights in educational sector in Indonesia are also high. Higher education becomes the medium in educating Indonesian Muslim women. The establishment of Pusat Studi Wanita (PSW)/ Women Studies Center in many Islamic universities and colleges shows the great attention given by higher education institution towards women's role (Kull, 2009: 30).

In the relation between men and women, it also needs to see the historiographical context socio-cultural condition in pre-Islamic era. The Holy Qur'an explains as well as informs how the real interaction between men and women is. The history of civilization in pre-Islamic period showed a picture of domination by men's world towards women's rights. During the 
jahiliyah period in Arab, a father would kill a daughter born in his family. In Europe, the condition of women was also concerning, where a husband could sell his wife to other man. A man also could give his wife for some time to other man in exchange of an amount of wages (Hanapi, 2015: 15). So dreadful the condition of women in the dark ages, that Allah tells in the Qur'an how angry and furious a father could be upon hearing his wife giving birth a daughter (Qs. An-Nahl [16]: 58).

The domination subjugation and submission historically shows a patriarchal force that tends to characterize oppression towards women's rights in their social sphere. The narrative text of the Qur'an revealed by God has a mission to unravel the conditions of cultural oppression to women that were happening at that time. Relationships of men in a marriage are not presented in the form of hegemony and submission by a group of human to other human. It is presented in a love, even protection. God explained that a man becomes clothes for his wife and vice versa (Qs. Al-Baqarah [2]: 187). Clothes are symbolic form for the obligation to cover each other's weakness. The husband will cover his wife's weakness, and vice versa. The presence of God's narrative is to show how to act towards their partners. The process of domination of submission, even structural oppression, is changed into the concept of mutual support and protection. Clothes have the ability to protect, so each party will carry out the process of protection to his/her partner. There is a will to protect each other between humans.

The process of protecting is also given to women, so she expands the meaning of protective clothes by applying it to her wider social group. Women can protect their social environment through their active roles and movements. The process of becoming a protector for themselves and their environment has been carried out by many women since the arrival of the Holy Qur'an narrative. The presence of Admiral Malahati in the Sultanate of Aceh, the Leadership of Tjut Nya' Dien in Aceh War, Dewi Sartika, Rasuna Said, Nyi Ageng Serang, and many others are actually forms of Muslim women taking an active role as clothes in the process of protecting themselves and their social environment. Before the law, they are equal legal subject to men, especially in marriage institutions (Irawaty \& Darojat, 2019: 61).

Awareness on the importance of self-protection, including their social environment, women basically become an entity who carries out her social role. Education to women is an initial milestone in how women interpret God's will in socio-religious relations. Women as figures who able to utilize the ability of their minds to position themselves as an agent of social change. Thinking, logic, and knowledge become weapons for her, with which she becomes perfect. Awareness to maximizing their logic to explain the ideas of the Holy Qur'an for human, especially women, must be directed to foster collective awareness (Bashori, 2020:65).

An awareness is being expected to be a driving force for reducing the understanding of domination, which is far from the teaching in Qur'an itself. The process of domination by men in social arenas seems to be more shaped by cultural ideas. Domination might be born from cultural structure space, while the religious teaching teaches about equal relationship based on deeds. It is one strategic role that can be played by both men and women in various social arenas. Cultural meanings which interpret various religious texts need to be understood. Culture essentially places a person in order and discipline. Behavioral patterns are regulated and determined by their normative standards for each activity carried out by a group, family, clan, nation, or class (Dewey, 1998: 15).

Culture will control every social group in an arena, where each group is involved in various relationships. Order in relationships is controlled, arranged to create an order and social order. The patriarchal cultural paradigm places men as controllers of this social order. He manages to control, subdue until he tries to manipulate. Then culture is not a static and empty space. It will be influenced by various values that enter the social arena so that culture can slowly change. Culture formed by a dynamic human mind concept is also able to transform itself to accept all changes. In this context, Islamic feminism movement emerged as an effort to change some 
cultural settings which considered unfair. Re-actualization of the teachings contained in the Holy Qur'an also helped to sow renewal in this cultural paradigm. Justice and freedom of action are carried out to try to put a fairer idea on the position of women who sometimes marginalized.

A freedom of action for women is a manifestation to the meaning of God's justice for humans. The narrative of Holy Qur'an shows a principle of justice which must be upheld by every human being. Justice is a necessity which is an objective law, and does not depend on personal desires and cannot be changed (Madjid, 2010: 183). Religious dimension opens the discourse of understanding on the creation of a transformation of changes value in the culture of a group of people. Cultural understanding in the past once considered women unfit for higher education, but now millions of women in Indonesia and elsewhere are starting to be able to enjoy higher education. In the past, the role of women was subordinated to domestic roles, whereas now the public sphere has accommodated many roles for women in it. This is a transformation of values that continues to run, and provides a space of change for the meaning of women in law.

Basically, this transformation of cultural values is not a form of efforts to show a protest to God (Djuned, 2011: 166). Yet, it is essentially a form of complaint towards cultural structure that doesn't give enough room to what has been instructed by God towards women. The narrative of the Holy Qur'an doesn't subjugate or dominate women, even respect women and any other human being in general according to their capacity (Muhibbin, 2011: 110).

Allah is the only entity of God Almighty (tauhid), and those besides Him, namely the living beings, are created in pair. Other than Him, all of the realities are created in pair, such as the creation of morning and afternoon, the moon and the sun, land and sea, joy and sadness, as well as rational reasoning with masculine character and soul intuition with feminine character, all of which shows the realities of pairs. Likewise, humans are created in the form of pairs between men and women. Men are symbolized as strength and power, and on the other side there are women who get the symbol of tenderness and affection. Woman was created from the rib of man and makes women a place to lean for weary men. Ribs are a component of God's creation that serves to support heavy burden of a tired body to lean down. Without ribs, a tired body cannot lean. So God created women to be a peaceful place (Qs.ar-Rum [30]: 21), because in them tired body can rest.

This paired reality in the construction of the duality of beings distinguishes that Allah is the one and only Singular Reality. Thus, a marriage that connects men and women is not interpreted as a submission and subjugation of women. Men have been paired with women by God in the form of a marriage, thus marriage is an institution that manifest the reality of paired beings to complement each other. Woman are created from man's rib, therefore woman have two qualities that go with their character. The first trait is the trait in their root as man, and the second trait is the nature of woman as how they created (Murata, 1996: 248).

From the symbols and the nature of women who bear those two qualities that is the characteristic obtained from their roots from man's rib and the nature of the creation as woman, women are ontologically able to do the general things that usually done by men. Women often able to carry out duties in men's fields, because they came from man's rib. They also able to perform patriarchal works as well as they perform women's duties as their creational nature. Women can work as good as men in doing their works, and they can also get education, same as men. The power of women to be able to act and do like men is actually a form of God's desire for beings. In masculine and feminine relations, the power relation model should be questioned. The process of submission, subjugation, control, and also domination needs to be rethought deeply.

The narrative of the Holy Qur'an which gives breadth and even liberates women is not also stated as a liberal theology. In its capacity as a space that provides and presents rights for women, the narrative of the Holy Qur'an returns the role and function of women as the initial form desired by Him. Women with all their rights do not free themselves from the existence of an 
objective narrative of God's laws for themselves. Women by nature are not to be dominated in power relations. They became a component in the series, and even the bonds of life of men. This is where the narrative of the Holy Qur'an glorifies women as men's accident, not putting it in a subordinate concept.

In the realm of historical historiography of Islamic civilization, it appears that the Prophet Muhammad saw a process of social transformation for the Arab's jahiliyah community. The pressure of oppression, until the murder of female infants as a tradition of pre-Islamic jahiliyah was fundamentally changed by the Prophet Muhammad. He not only explained in the narrative, but further carried out in concrete action (Latif, 2018: 293). The concept of subjugation in gender relations in the pre-Islamic Arabic tradition was changed into a complementary and covert affection relationship (Qs. Al-Baqarah [2]: 187). The fundamental right of equality appears as an equal being before God (Qs. An-Nahl [16]: 97). This equality before God principle taught by the Prophet Muhammad erased the jahiliyah culture in pre-Islamic period. The new dimension of relations presented in the narrative of the Holy Qur'an brought a profound change in tradition, especially in the jahiliyah community, until now. The religious foundations that reorganized the relations of women and men have been embedded in the socio-cultural dimension of Arab society, and now they are creeping in every tradition of Islamic society.

The strategic role of women in the midst of their socio-cultural environment, both within their family and as part of a nation/country, can be seen in three ways: First, women as a wife who play role as partner, motivator, and advisor to their husbands. A wife's role is to provide advice needed for her husband in every problem faced by the family. A wife provides solutions to solve the problems faced by her husband in managing the household. Second, women as mothers will act as educators in the midst of family institutions. Women in the middle of the family will become educators who teach moral values as well as intellectuality for their children. Mother is the closest parent figure in the environment of her children, where children get the very first education precisely from their mother. Third, women in their social environment will become a solid pillar of the country. The glory and the collapse of a nation is determined by the quality of women in the middle of the nation. The education they give to their children will be carried over time and have a profound influence on the socio-cultural environment. Nations formed from family community units will form themselves based on values implanted in family units (Rasyidah, 2019).

Feminism in the teachings of Islam takes the core of the heart of Islam itself, rather than understanding incorporating the value of European feminism into the body of Islamic thought. Islamic feminism can refer to its basic foundation, which is the narrative of the text of the Holy Qur'an itself. The narrative of the Holy Qur'an, in several verses, explains God's laws in giving the highest regard for the position of women. Lester and Spoerri (1997) revealed that an experience of an event that detrimental to humans was part of the process of maturity. A historical event of submission and domination of women in their socio-cultural environment has been able to mature women. They have been able to become figures who able to play an active role in determining the course of human civilization.

\section{Conclusions}

The conclusion obtained from this research is that in the narrative approach of the Holy Qur'an, there was no significant power relation that subjugates, dominates, or gives a subordinate role to women in Islam. Spatial structure of a culture becomes a matter of concern when there is a submission on the role of women in their socio-cultural environment. The narrative text of the Holy Qur'an explains the high appreciation of domestic and public roles for women. Feminism itself can be traced in various narrative texts of the Holy Qur'an that place women in a place of honor. It is seen that the position of a balanced gender relation gets its 
strength in Islam through the narrative text of the Holy Qur'an. This balanced relationship between men and women is drawn from the heart of Islam itself.

In theoretical approach to gender relations developed by Sachiko Murata, there is a conclusion that gender relations are associated with strong Islamic spiritualism ideas. It is not merely produced by rational reason, but also by spiritualism contained in the narrative text of the Holy Qur'an. Gender relations show the difference between the concept of the duality of beings and the singular reality of God Almighty. Single reality is at the top of the hierarchy of power that controls the universe as a macro-cosmos, and human as a micro-cosmos.

\section{Acknowledgements}

This research did not receive any specific grant from funding agencies in the public commercial, or not-for-profit sectors.

The authors declare no competing interests.

\section{References}

Bashori, A. (2020). Filsafat Hukum Islam, Paradigma Filosofis, Mengais Kebeningan Hukum Tuhan [Islamic law philosophy, philosophical paradigm: Scavenging the transparency of God's Law]. Jakarta, Penerbit Prenadamedia Group.

Dewey, J. (1998). Budaya dan Kebebasan, Ketegangan antara Kebebasan Individu dan Aksi Kolektif [Culture and freedom: Tensions between individual freedom and collective action]. Jakarta, Yayasan Obor Indonesia.

Djuned, D. (2011). Antropologi Al-Qur'an [Anthropology of Qur'an]. Jakarta, Penerbit Erlangga.

Ghosh, H. A. (2009). Introduction: Gender and Islam in Asia, Journal of International Woman's Studies, Bridgewater State University, 11(1), 1-4. Available at https://vc.bridgew.edu/cgi/viewcontent.cgi?referer=https://www.google.com/\&httpsredir=1\& $\underline{\text { article }=1144 \& \text { context }=\text { jiws }}$

Hanapi, A. (2015). Peran Perempuan dalam Islam [The role of women in Islam]. Jurnal ar-Raniry, 1(1), 1526. http://dx.doi.org/10.22373/equality.v1i1.620

Irawaty \& Darojat, Z. (2019). Kedudukan dan Peran Perempuan dalam Perspektif Islam dan Adat Minangkabau [The position and role of women in the Islamic perspective and Minangkabau customs]. Indonesia Journal of Multidisciplinary Islamic Studies, 3(1), 59-76. https://doi.org/10.21009/003.1.04

Kull, A. (2009). At the forefront of a post patriarchal Islamic education: Female teachers in Indonesia. Journal of International Woman's Studies, Bridgewater State University, 11(1), 25-39. Available at https://vc.bridgew.edu/jiws/vol11/iss1/3.

Latif, M. (2018). Islam and feminism theology. Journal of Islamic Civilization in Southeast Asia, 7(2), 288313. https://doi.org/10.24252/jicsa.v7i2.7338

Lester, J., \& Spoerri, P. (1997). Menemukan Kembali Kebebasan [Rediscovering freedom]. Jakarta: Penerbit Grafiti.

Madjid, N. (2010). Islam Agama Kemanusiaan, Membangun Tradisi dan Visi Baru Islam Indonesia [Islam, religion of humanity: Building a new tradition and vision of Indonesian Islam]. Jakarta: Paramadina. 
F. F. Wasitaatmadja, Susianto \& Suartini - The Relation of Gender and Feminism in ...

Muhibbin, Z. (2011). Wanita dalam Islam [Women in Islam]. Jurnal Sosial Humaniora, 4(2), 109-120. DOI: http://dx.doi.org/10.12962/j24433527.v4i2.627

Murata, S. (1996). The Tao of Islam, Kitab Rujukan tentang Relasi Gender dalam Kosmologi dan Teologi Islam [The Tao of Islam: Book of reference on gender relations in Islamic cosmology and theology]. Bandung: Penerbit Mizan.

Nurmila, N. (2011). The influence of global Muslim feminism on Indonesia Muslims feminist discourse. AlJamiah Journal of Islamic Studies, UIN Sunan Kalijaga, 49(1), 33-64. https://doi.org/10.14421/ajis.2011.491.33-64

Priyanto, J. (2017). Wacana, Kuasa dan Agama, dalam Kontestasi Pilgub Jakarta, Tinjauan Relasi Kuasa dan Pengetahuan Foucolt [Discourse, power and religion in the contestation of the Jakarta Pilgub: Review of the relationship of power and knowledge of Foucolt]. Jurnal Thaqafiyyat, 18(1), 186-200. Availabe at http://ejournal.uinsuka.ac.id/adab/thaqafiyyat/article/view/1316/797

Rasyidah, K. (2019). Glory of women in family (Islamic feminism perspectives). Jurnal Pemikiran dan Pendidikan Islam Studi Religia, 3(1), 1-9. http://dx.doi.org/10.30651/sr.v3i1.2938

Susanto, A. F. (2019). Filsafat \& Teori Hukum [Philosophy and legal theory]. Jakarta: Penerbit Prenadamedia Kencana. 